The high-temperature nitration of paraffins and substitution chlorination of olefines are recent technical developments of great significance. The $\alpha$-methylenic halogenation reaction can now be conveniently effected in the laboratory under mild conditions by employing $\mathrm{N}$-bromosuccinimide. The remarkable orientating effect of organic peroxides on the addition of hydrogen bromide to olefines has led to the discovery of other chain reactions, of considerable preparative value, initiated by these trigger catalysts.

\section{THE GRID AND SECONDARY POWER STATIONS IN GREAT BRITAIN}

IN a paper entitled "The Effect of the National 1 Grid on the Operation and Maintenance of Secondary Power Stations" read before the Institution of Electrical Engineers in London on April 1, R. A. W. Connor discusses the status and function of these stations in relation to the Grid in Great Britain, together with some of the running and maintenance problems brought about by Grid operation, and some of the factors affecting cost of production. The paper directs attention to the important part played by the secondary power stations, the efficient and economic operation of which has undoubtedly contributed in no small measure to successful Grid operation, and to the benefit of the supply industry as a whole.

The following conclusions are reached as a result of the study. The general shape of the national load curve will remain for many years and will not necessitate radical changes in station design. The reclassification of every station through its normal working life must continue, and it would be uneconomic to lay down plant or stations specifically to deal with peak loads only. Future load curves may exhibit exceptionally high rates of change of loads during certain periods, but the capacity of secondary stations will increase and it is unlikely that any new plant will have to be relegated to secondary duties until some years of primary station duties have been completed.

Improvement in the average thermal efficiency of secondary stations will continue owing to the relegation to this class of more modern stations with higher steam pressures and temperatures. There is scope for further improvements in operation and maintenance, although running conditions and high banking losses impose a lower limit on station efficiency than is the case with base-load stations. Grid operation with its daily cycle of temperature changes has affected maintenance and repair work in secondary stations, but not seriously or to the detriment of plant.

Owing to the large variations in output encountered under two-shift, one-shift and peak-load operation, and also cue to the high fixed-cost component, all station costs tend to vary in inverse proportion to the kilowatt-hour output, and comparisons need very careful interpretation to be of any value. A characteristic curve, hyperbolic in shape, correlating output and cost, can be built up for any station. Most secondary stations are called upon at varying intervals and seasons to work with very low outputs, in which $\mathbf{r}$ gion the characteristic shows a very sharp upward trend. Due to the predominating effect of running conditions on thermal efficiency and to the sharp upward trend of the unit cost at low outputs, many secondary stations have suffered reductions in thermal efficiency and increased costs as a result of Grid operation. This, however, has enabled the primary stations to operate under base-load conditions and the full financial advantages of 'Grid operation to be realized.

\section{LOCATION OF INDUSTRY IN GREAT BRITAIN}

HE paper on "Location of Industry" which Mr. R. G. Glenday, economic adviser to the Federation of British Industries, delivered before the Royal Society of Arts on February 10, roundly challenges current views on the location of industry, including some expressed in the Barlow Report, but his emphasis on the background of change against which the problem of industrial location should be viewed cannot fail to be stimulating, although apart from its provocativeness his paper offers little in the way of constructive suggestion. Fundamentally, Mr. Glenday reminds us, the problem of locating a country's industries and urban centres is part of the larger problem of adjusting a population to its environment, and it is the exceptional rate of growth of populations and industries during the last century and $a$ half that has given rise to so many acute economic problems to-day. He regards the closing of the channels of international movement, following on the disappearance of the geographical frontiers of the civilized world by the first decade of this century, as the major event responsible for bringing to a close the era of democracy and free capitalism in many parts of Europe.

The problem of industrial location must be examined against this background, and Mr. Glenday argues next that the two main factors which determined the location of industry in Great Britain, particularly the move northwards in the nineteenth century, were, first, the development of the railway and steamship, coupled with the adoption of free trade, and, secondly, the development of road transport and electrical transmission in the twentieth century. With this, from 1931 onwards, was associated a re-direction of the 'growing-point' of Britain's industrial energies to home rather than to export activities. Most discussions on the location of industry tend to under-estimate the effect of such basic structural innovations, which affect the general lay-out as well as the skeleton of the economic system.

Mr. Glenday, like the Federation of British Industries, seems to be rather obsessed with difficulties, but more creative and adventurous minds may profit by his warnings without being deterred by them. He rightly directs attention to the importance-and the difficulty-of deciding which industries and occupations are essential parts of developing urban structures and which can be regarded as independent and mobile. He stresses also the vital importance of timing in industrial progress. Tke two main questions which require examination in regard to post-war location are first, the probable size and quality of the population involved, and secondly, the probable direction of the forces of economic evolution affecting the occupation of that population. In regard to the first, he observes that in the main the question will be the redistribution of a stationary or even a declining population; and in regard to the second, 
he stresses the place of services rather than industry in providing the main channels of expanding employment.

Discounting somewhat the magnitude and significance of the drift to the south of England, though rather uneonvincingly, Mr. Glenday attributes this migration to improved road transport, more flexible forms of power and the diversion of our industrial energies from foreign to home trade. The tendency of the newer occupations to be in service trades and luxury products requiring elaborate packing and careful handling as well as servicing after sale has made proximity to the main market a factor of growing importance. Moreover, the pre-war trends have been almost entirely reversed during the War. Stagnant industries have revived and expanded beyond belief and other industries have been scaled down and concentrated. These changes have been accompanied by a migration of population and industrial location in a direction entirely contrary to that of the past two decades.

The primary reconstruction problem, therefore, according to Mr. Glenday, will not be so much one of choosing the regions in which the new industries are to be established, as of selecting those in which over-expanded war industries are to be contracted. The days of expansion are ended, and in a period of increasing industrial efficiency we will have our stagnant population rapidly growing older. In the near future our main industrial pre-occupation is likely to be the development of alternatives and artificial substitutes for traditional raw materials, and replacement and concentration in existing industries and production centres. Mr. Glenday concludes by emphasizing the trend towards concentration of industry, in the sense of less labour and investment for more and more work, and that questions of industrial location and the redistribution of population will be increasingly settled in consultation with the State or with the authority responsible for dealing with the lay-out and planning of our towns and countryside.

There can be no doubt as to the importance of the new factors to which Mr. Glenday directs attention, and they will require close consideration in the planning of town and countryside which will be involved in post-war reconstruction. The picture he paints, however, is one-sided. $\mathrm{He}$ dismisses too cavalierly the problem which the depressed areas must again present when the war production programme terminates. $\mathrm{He}$ ignores the opportunities which dispersal of population, evacuation, and bombing have given us, and refuses to face the central fact that location of industry cannot be left unguided in the hands of private interests. No one could pretend that the location of industry is other than a difficult and complicated problem, any more than it can be seriously maintained that the growth of our larger towns or conurbations and the concentration of industry in London and the south-east of England has not distorted the national economic structure and imposed serious handicaps on the health and social welfare of the nation. Difficulties are no excuse for inaction, and however cautiously the problem is approached, the location of industry and the redistribution of the industrial population is an essential part of the larger problem of planning the resources of Britain to afford the maximum social and economic satisfaction to the population as a whole; and of providing such services as transport, amenities and recreation, health and occupation.

\section{FORTHCOMING EVENTS}

(Meeting marked with an asterisk * is open to the public)

Saturday, May 15

Free German Institute of SoIfNCE and Learning (at 16 Buckland Crescent, London, N.W.3), at 5 p.m.-Dr. O. Godart: "Belgian Scientists and the War". Monday, May 17

ROYAL Societr of ARTS (at John Adam Street, Adelphi, London, w.C.2), at 1.45 p.m.-Prof. H. v. A. Briscoe : "Some New Properties of Inorganic Dusts" (Cantor Lectures, I).

ROYAL GEOGRAPHIOAL SOCIETY (Kensington Gote, London, S.W.7), at 5.0 p.m.-Major G. W. Morey : Kodachrome fllms of Algeria and Moroceo.

Tuesday, May 18

PHYSICAL SOCIETY (at the Royal Institution, 21 Albemarle Street, London, W.1), at 5 p.m.-Prof. E. T. Whittaker, F.R.S.: "Chance, Freewill and Necessity in the Scientiflc Conception of the Universe" (twenty-seventh Guthrie Lecture).

\section{Wednesday, May 19}

ROY $\triangle L$ SOCIETY OF ARTS (at John Adam Street, Adelphi, London, W.C.2), at 1.45 p.m.- "Agriculture To-day and To-morrow", 10 ? Sir John Russell, F.R.S.: "Our Agriculture--its Relation to Ourselves and Others".

INSTITUTh OF ChEMISTRY (LONDON AND SOUTH EASTRRN COUNTIES SECTION) (at the Institute of Chemistry, 30 Russell Square, London, W.C.1), at 6 p.m.-Dr. J. W. Cuthbertson "Recent Advances in Electro-Metallurgical Industry". INSTYTUTE OF METALS (at the Institution of Mechanical Engineers,
Storey's Gate, London, S.W.1), at 6 p.m.-Prof. G. P. Thomson, F.R.S.: "Electron Diffraction" (thirty-third annual May Lecture). INSTITUTe of PHYsics (LONDON AND HOME COUNTIFS' BRANCH) (JOINT MEETING WITH THE ARISTO'TELIAN SOCIETY AND THE MIND Association) (at the Royal Institution, 21 Albemarle Street, London, W.1), at 6 p.m.- Conference on "The New Physics and Physieal Materialism". Addresses by Prof. Susan Stebbing and Sir James Jeans, O.M., F.R.S.; discussion will be opened by Mr. R. B. Braithwaite and Prof. E. T. Whittaker, F.R.S.

\section{Thursday, May 20}

INSTITUTE OF FUEL (at the Institution of Mechanical Engineers, Storey's Gate, London, S.W.1), at 5.30 p.m.-Mr. O. W. Roskill: "Statistics in the Fuel and Power Industries".

\section{Friday, May 21}

INSTITUTION OF ELEOTRICAL ENGINEERS (MEASURHMENTS SRCTION) (at Savoy Place, Victoria Embankment, London, W.C.2), at 5 p.m.Dr. E. H. Rayner: "Measurement of Small Quantities",

ROYAL INSTITUTION (21 Albemarle Street, London, W.1), at 5 p.m.Dr. H. J. Plenderleith: "The Preservation of Museum Objects in War-time".

UNIVERSITY OF DURHAM PHILOSOPHICAL SocIETY and KING's COLLEGE PURE SoIENCE SOCIETY (at King's College, Newcastle-uponTyne), at 5.15 p.m.-Prof. Max Born, F.R.S.: "Experiment and Theory in Physics".

Saturday, May 22

NUTRITron Society (at the London School of Hygiene and Tropieal Medicine, Keppel Street, London, W.C.1), at 10.30 a.m.--Conference on "Nutrition in Infaney" (Chairman: Prof. L. G. Parsons).

FREe German INSTTTUTe OF Sctence AND LearNing (at 16 Buckland Crescent, London, N.W.3), at 5 p.m.-Dr. G. Coumoulos: "The Greek Scientists-Traditions and Ties".

\section{APPOINTMENTS VACANT}

APPLICATIONS are invited for the following appointments on or before the dates mentioned :

Senior Lecturer in Crvil Enginerering-Principal and Clerk to the Governing Body, Wigan and District Mining and Technical College, Wigan (May 22)

LECTURER IN Mechanical EngINEERING for the Schools of Technology, Art and Commerce, Oxford-Chief Education Officer, City Education Office, 77 George Street, Oxford (May 22).

TURBINE SUPERINTENDENT AND MAINTENANGE ENGINERR at the Generating Station of the County Borough of Brighton Electricity Undertaking-The Engineer and Manager, Brighton Electricity Undertaking, Electric House, Castle Square, Brighton 1 (endorsed 'Turbine Superintendent') (May 29)

Borodgh Electrical Engineer and Manager--The Town Clerk, Town Hall, Leyton, London, E.10 (May 31)

TRAOHRR IN MATHEMATICS AXD Mechanics in the Technical School, Norwich City College and Art School-Director of Education, City Hall, Norwich (June 5)

CITY BACTERIOLOGIST-The Town Clerk, Municipal Buildings, Dale Street, Liverpool 2 (June 30).

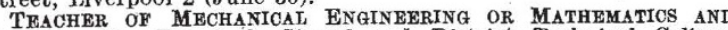
PHYsics-The Principal, Stroud and District Technical College, Kendrick Hall, Stroud, Glos.

CHIEF ENGINEER, with experience of high-power high-speed petrol and Diesel machinery, in a shipbuilding and marine engineering firmMinistry of Labour and National Service, Appointments Offee, 16 Westwood Road, Southampton.

LFCTURAR IN BIOLOGY - The Principal, St. Katharine's College, (Liverpool), at the Queen's Hotel, Keswick. 